\title{
Maine Head Start Report: 2017
}

Jessica A. Carson, Carsey School of Public Policy

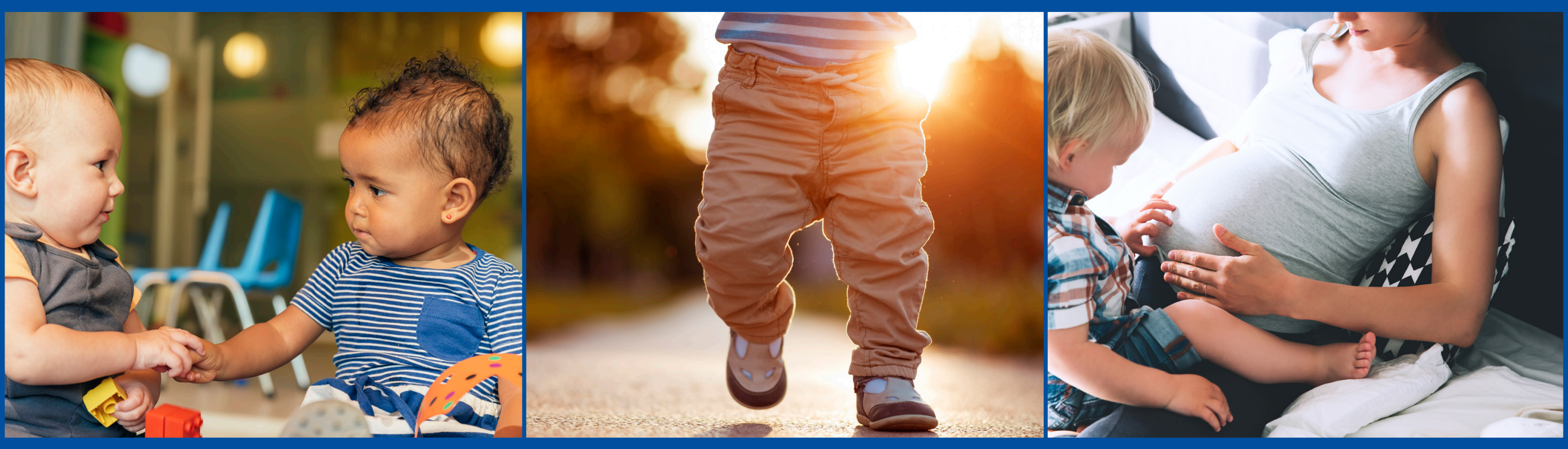

JOHN T. GORMAN

$\begin{array}{llllllllll}\mathbf{F} & \mathbf{O} & \mathbf{U} & \mathbf{N} & \mathbf{D} & \mathbf{A} & \mathbf{T} & \mathbf{I} & \mathbf{O} & \mathbf{N}\end{array}$

University of New Hampshire

Carsey School of Public Policy 


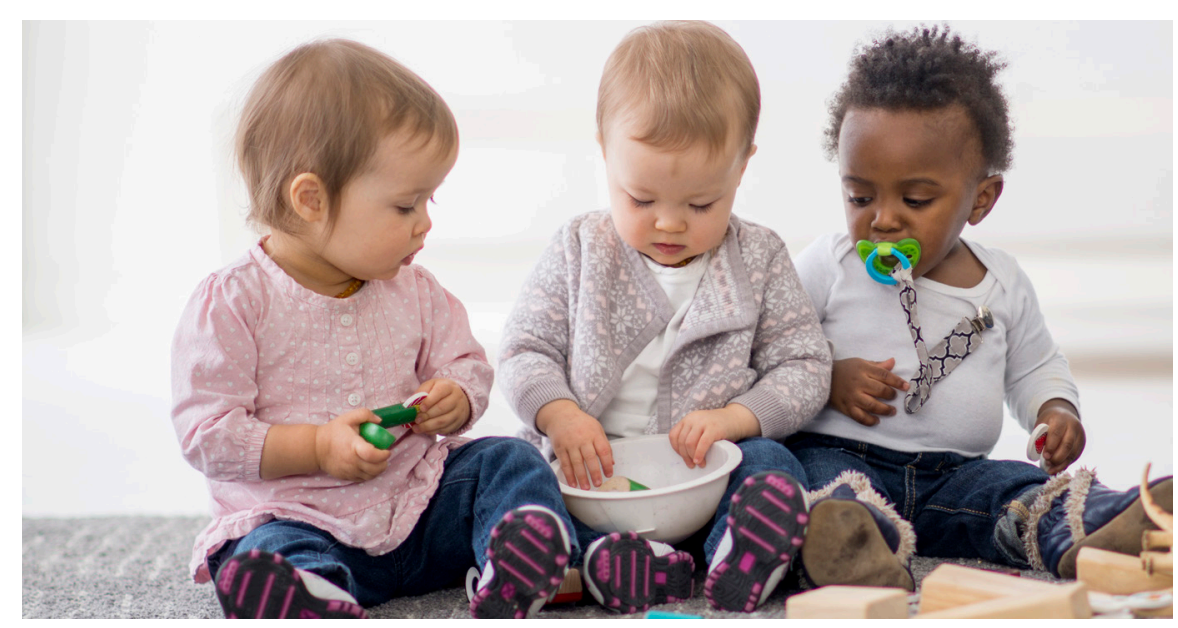

\section{What Are Head Start and Early Head Start?}

Founded in 1965, Head Start is designed to promote "school readiness of children under 5 from low-income families through education, health, social, and other services." Created in 1994, Early Head Start focuses specifically on the youngest children-those under age 3, and pregnant women-and provides "early, continuous, intensive, and comprehensive child development and family support services to low-income infants and toddlers, and their families, and pregnant women and their families."2 The Administration for Children and Families, housed within the U.S. Department of Health and Human Services, oversees and administers all Head Start programs through the federal Office of Head Start.

\section{Head Start Locations and Enrollment In Maine}

The state of Maine has sixteen Head Start grantees, operating eleven Head Start (HS) programs, three American Indian \& Alaska Native Head Start (AIAN HS) programs, and thirteen Early Head Start (EHS) programs (see Table 1). In the 2015-2016 program year, sites operated by these sixteen grantees served 4,126 children and pregnant women. ${ }^{3}$

\section{Table 1. Maine Head Start Grantees}

\begin{tabular}{|c|c|c|}
\hline GRANTEE & PROGRAMMING & LOCATION \\
\hline \multirow[t]{2}{*}{ Androscoggin Head Start \& Child Care } & HS & Lewiston, ME \\
\hline & EHS & \\
\hline Aroostook Band of Micmac Indians & AIAN HS & Presque Isle, ME \\
\hline \multirow[t]{2}{*}{ Aroostook County Action Program } & HS & Presque Isle, ME \\
\hline & EHS & \\
\hline \multirow[t]{2}{*}{ Child and Family Opportunities, Inc. } & HS & Ellsworth, ME \\
\hline & EHS & \\
\hline \multirow[t]{2}{*}{ Community Concepts, Inc. } & HS & South Paris, ME \\
\hline & EHS & \\
\hline \multirow[t]{2}{*}{ Kennebec Valley Community Action Program } & HS & Waterville, ME \\
\hline & EHS & \\
\hline Kennebec Valley Community Action Program & EHS-Child Care Partnership & Waterville, ME \\
\hline Maliseet Head Start & AIAN HS & Houlton, ME \\
\hline \multirow[t]{2}{*}{ Midcoast Maine Community Action } & HS & Bath, ME \\
\hline & EHS & \\
\hline Passamaquoddy Head Start & AIAN HS & Calais, ME \\
\hline \multirow[t]{2}{*}{ Penquis CAP, Inc. } & HS & Bangor, ME \\
\hline & EHS & \\
\hline \multirow[t]{2}{*}{ Southern Kennebec Child Development Corporation } & HS & Farmingdale, ME \\
\hline & EHS & \\
\hline \multirow[t]{2}{*}{ The Opportunity Alliance } & HS & Portland, ME \\
\hline & EHS & \\
\hline \multirow[t]{2}{*}{ Waldo Community Action Partners } & HS & Belfast, ME \\
\hline & EHS & \\
\hline York County Community Action Corporation & EHS-Child Care Partnership & Sanford, ME \\
\hline \multirow[t]{2}{*}{ York County Head Start } & HS & Sanford, ME \\
\hline & EHS & \\
\hline
\end{tabular}

Note: Kennebec Valley Community Action Program has been awarded two grants, but operates as single agency (per KVCAP Business \& Information Manager, 2/9/17). HS = Head Start, EHS = Early Head Start, and AIAN HS = American Indian \& Alaska Native Head Start. 
The majority of Maine Head Start enrollees (88 percent) participate in a center-based program; the most popular program option is part-week (four days) enrollment in a center (Figure 1). Most children (91 percent) enrolled in part-week programs are also enrolled for part-day programming (6 hours or fewer per day).

\section{Figure 1. Percent of Maine Head Start Enrollees by Program Type}

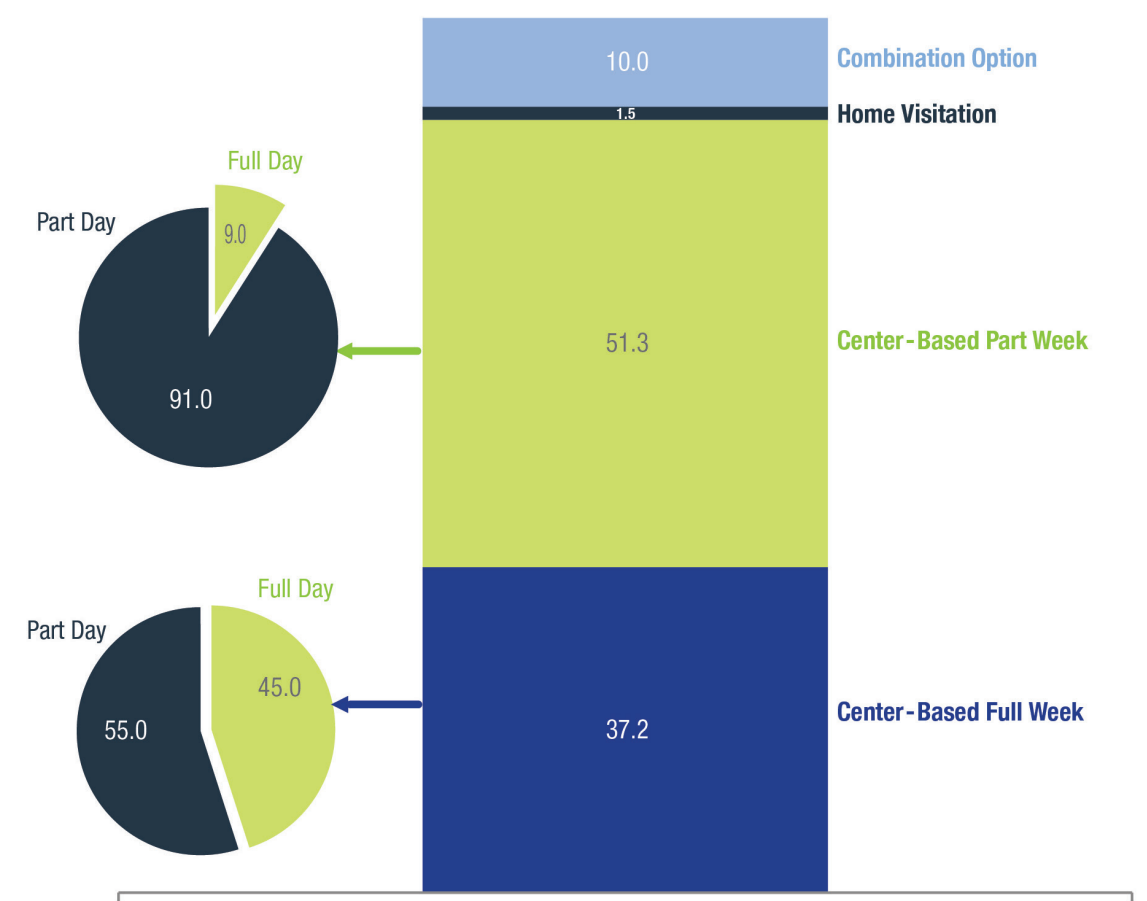

Head Start
Home visitation is the most prevalent arrangement among Early Head Start enrollees (47 percent) (Figure 2). This option includes weekly 90-minute visits from a home visitor and twice-monthly group activities for enrolled parents and children.

Figure 2. Percent of Maine Early Head Start Enrollees by Program Type

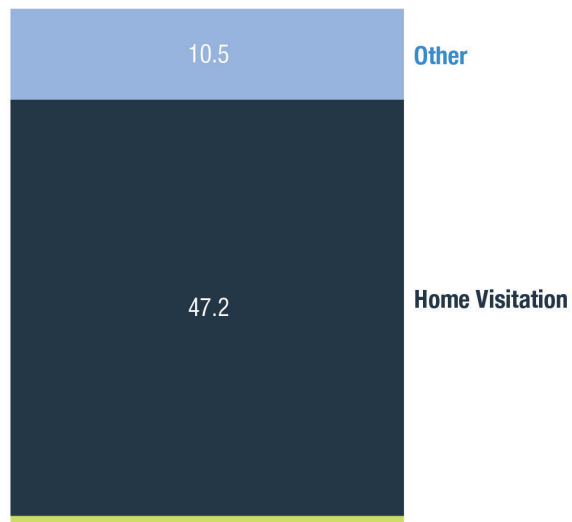

5.9 Center-Based Part Week
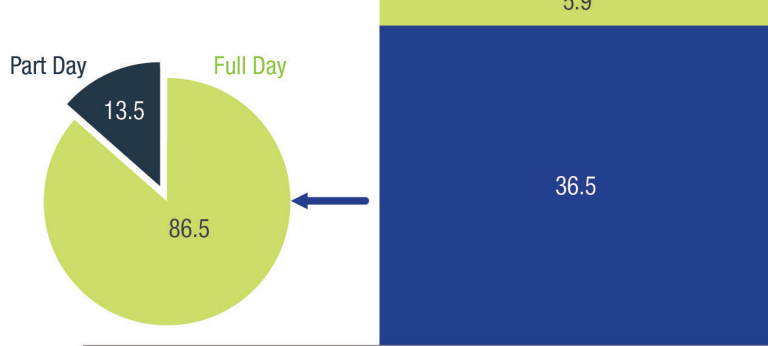

Center-Based Full Week

\section{Early Head Start}

Note: All center-based part-week enrollees attend full-day programming. "Other" includes a combination option (center-based and home visiting) and family child care option. 


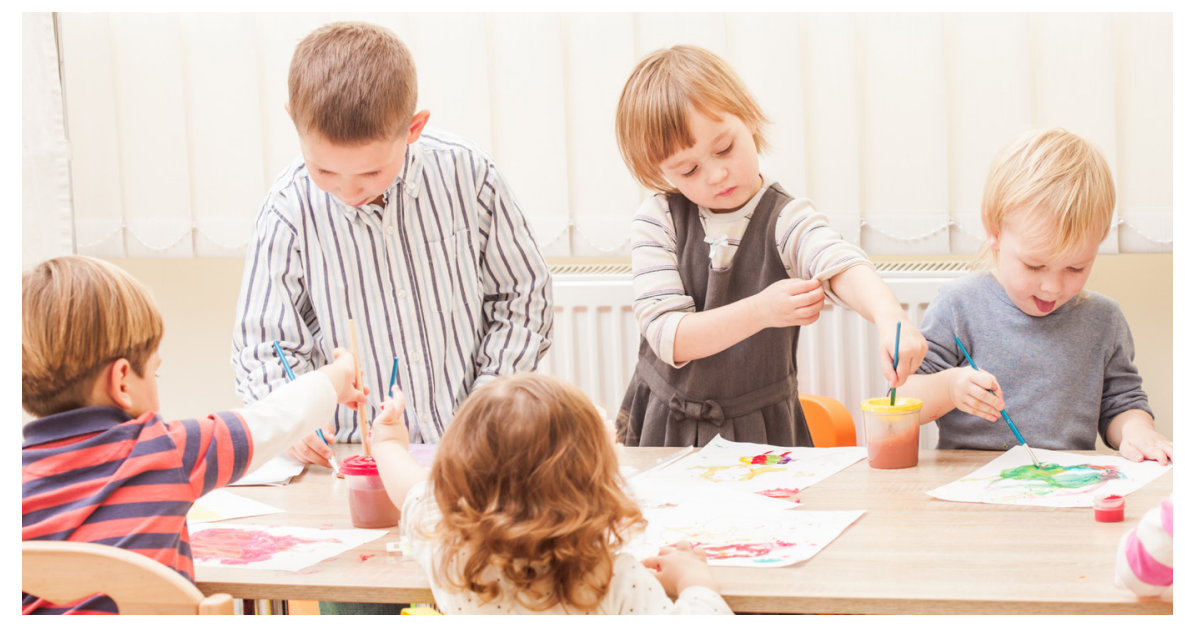

\section{Who Pays for Head Start?}

Head Start and Early Head Start programs are funded with grants from the federal government. Each year, Congress authorizes the amount of federal spending allocated to Head Start for the year, and grants are awarded directly to the agencies that operate programs in local communities (including public agencies, private organizations, tribal governments, and school systems). Additional funds or in-kind contributions are provided by state or local sources, or through other mechanisms like grants awarded to individual agencies [see Figure 3, although not all state funds are captured here (see figure note)].

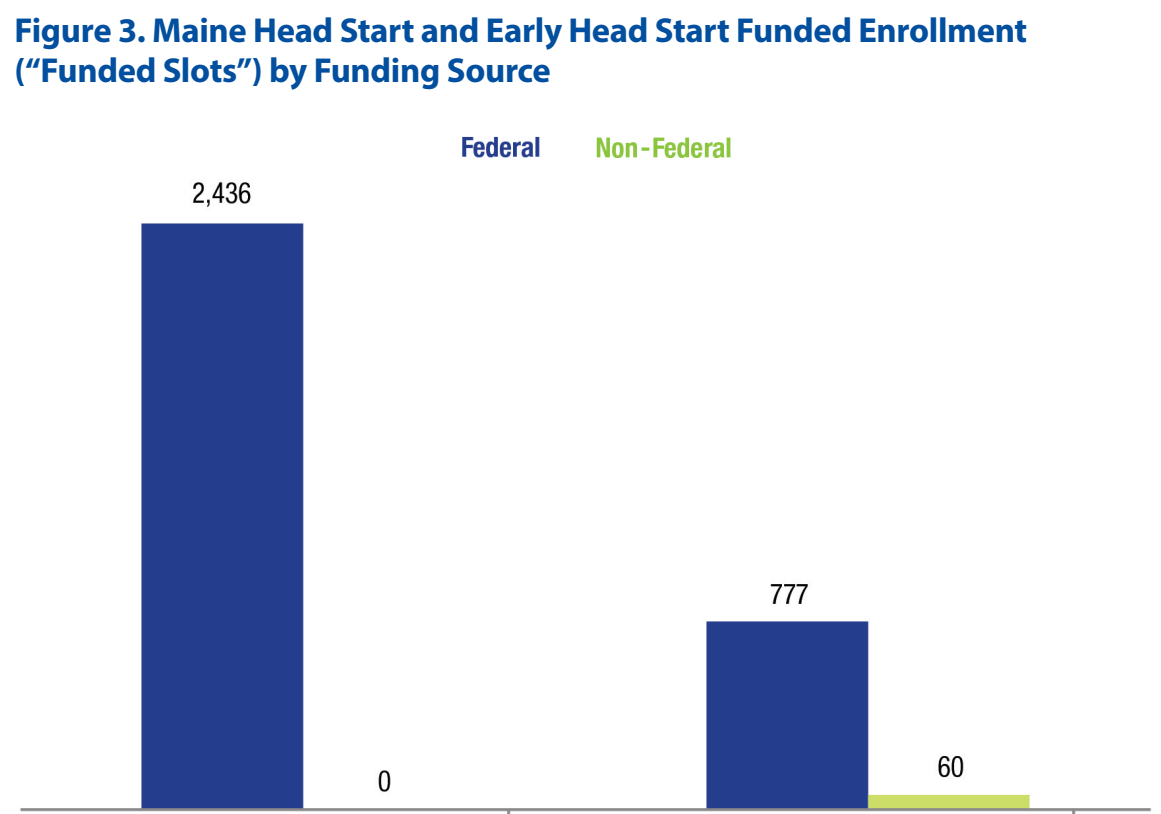

Head Start

Early Head Start

Note: According to the Office of Head Start, ${ }^{4}$ "funded enrollment numbers include enrollment slots funded by state or other funds when used by grantees as required nonfederal match. States may provide additional funding to local Head Start programs, and as such, is not included in the figure here. 
Federal funding for Maine Head Start programming remained relatively stable between 2004 and 2008 (Figure 4). In 2009, the American Recovery and Reinvestment Act increased investment for the purpose of expanding enrollment and improving the quality of the Head Start workforce. In 2013, Head Start experienced the largest funding cut in its history due to the federal budget sequestration. Congress restored these funds in $2014 .^{5}$

\section{Figure 4. Federal Funding for Maine Head Start and Early Head Start,}

2004-2015

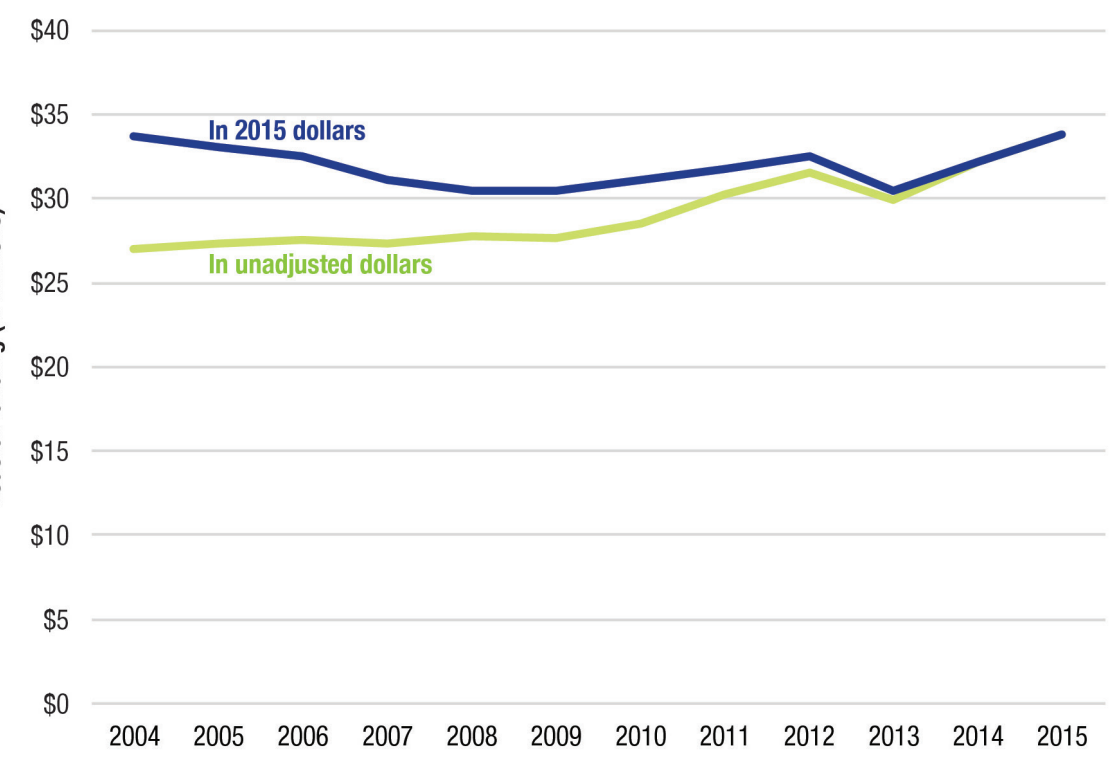

In fiscal year 2015, funded enrollment (or the number of available program slots) in Maine Head Start and Early Head Start reached 3,363 (Figure 5). A noticeable decrease in funded enrollment occurred in 2013, related to the budget sequestration (see also Figure 4). Funded enrollment remained slightly lower than pre-sequestration levels, perhaps related to changes in program regulations around increased program quality that meant less spending for enrollment. ${ }^{6}$

\section{Figure 5. Funded Enrollment for Maine Head Start and Early Head Start,}

\section{4-2015}

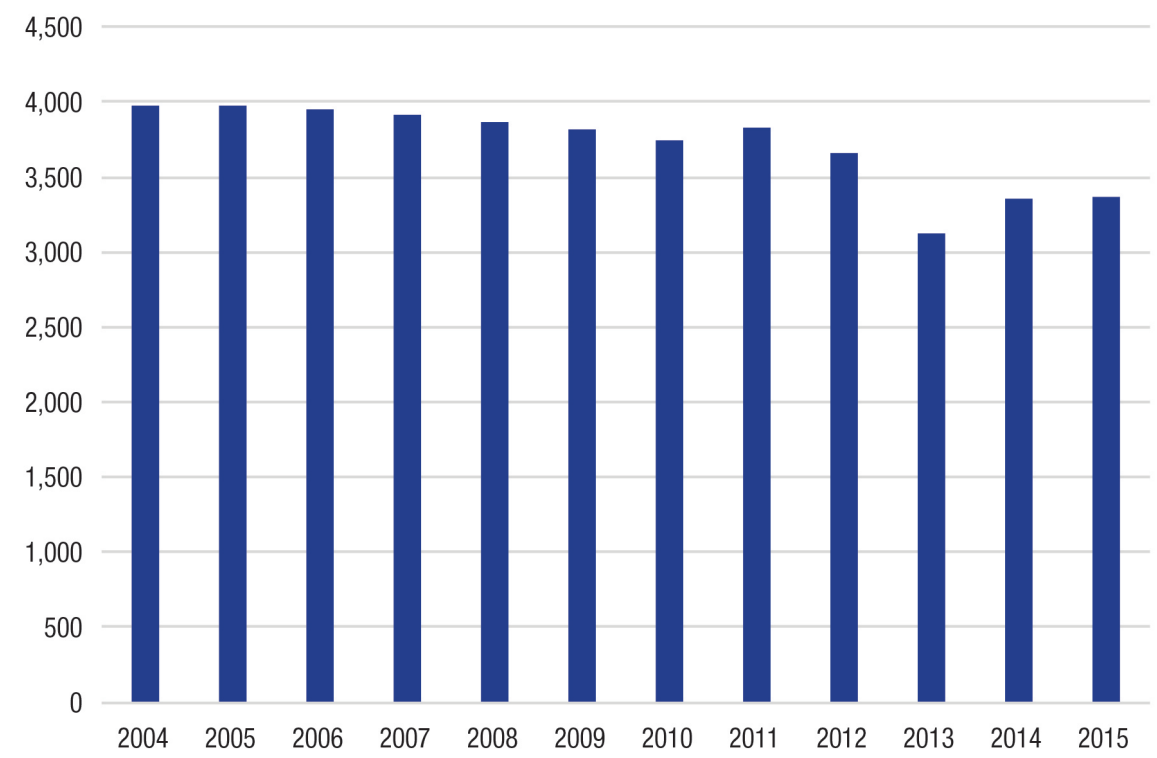

Note: Funded enrollment refers to fiscal year rather than program year. 


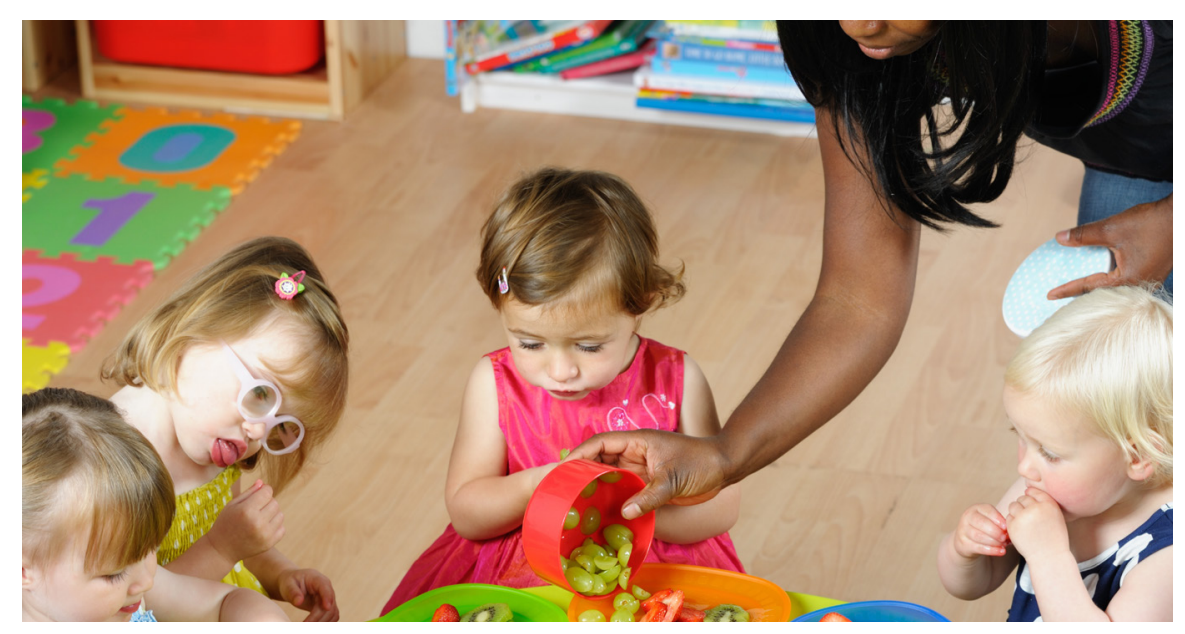

\section{Characteristics of Enrolled Children and Families}

Head Start and Early Head Start programming prioritizes the enrollment of poor families. Eligibility is established, in part, using the federal poverty guidelines (Table 2), ${ }^{7}$ and families who are poor are eligible for Head Start and Early Head Start services. In Maine, in program year 2015-2016, there were 3,273 funded slots for more than 14,000 poor children under age $5,{ }^{8}$ or less than a quarter of those needed to serve all potentially income-eligible children.

\section{Table 2. 2015 Federal Poverty Guidelines}

\begin{tabular}{cc} 
FAMILY SIZE & ANNUA INCOME \\
\hline 1 & $\$ 11,770$ \\
2 & $\$ 15,930$ \\
3 & $\$ 20,090$ \\
4 & $\$ 24,250$ \\
5 & $\$ 28,410$ \\
6 & $\$ 32,570$ \\
7 & $\$ 36,730$ \\
8 & $\$ 40,890$ \\
\hline
\end{tabular}

Note: For families/households with more than eight members, add $\$ 4,160$ per additional person.
In addition to poor families, certain families with higher incomes may be eligible for Head Start or Early Head Start, including if a child is homeless, is in foster care, or is the recipient of public assistance. While more than half of Maine's enrollees were eligible primarily because of their families' below-poverty incomes, about one-fifth were eligible because they received public assistance (Figure 6). ${ }^{9}$

Figure 6. Enrollment by Primary Eligibility Type, Maine Head Start and Early Head Start

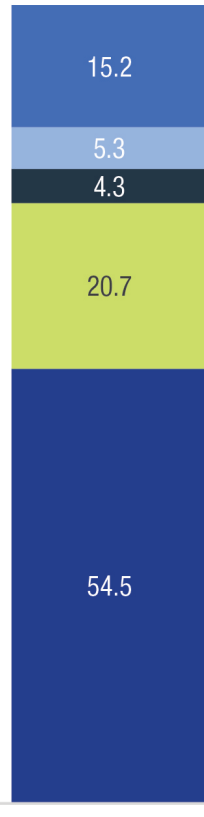

Over Income

Homeless Children Foster Children

Receipt of Public Assistance

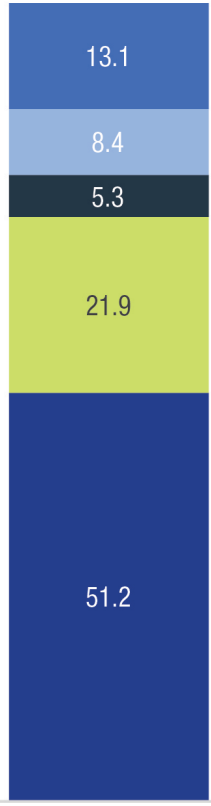

Head Start 
Children enrolled in Maine Head Start and Early Head Start range in age from before birth through age 5 (Figure 7). However, programming most often serves 4-year-olds.

\section{Figure 7. Age of Maine's Head Start and Early Head Start Enrollees}

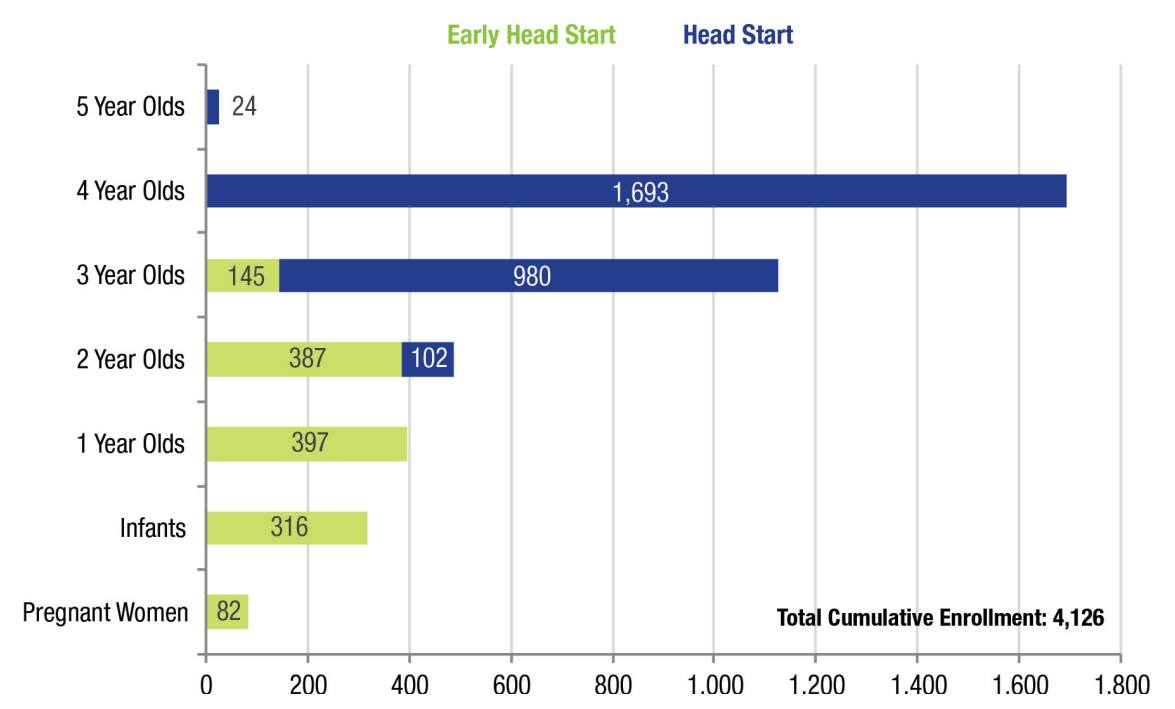

Note: Cumulative enrollment refers to the number of children/pregnant women who have attended at least one class or received at least one home visit during the program year.

\section{Box 1. Barriers to Serving Eligible Families}

Not all eligible children in Maine receive Head Start or Early Head Start services, and slots exist for less than a quarter of poor children. Limited funding is a major barrier to serving all eligible families, although other barriers exist. Maine Head Start directors cite transportation challenges, mismatches between program hours and families' work schedules, and the intensity of program expectations around attendance and participation as potential barriers to families' initial and continued enrollment. ${ }^{10}$
The majority of enrolled Maine families speak English at home (Figure 8), although non-English-speaking enrollees in Maine most often speak an African language (likely related to Maine's sizable population of immigrants and refugees from that continent). ${ }^{11}$

\section{Figure 8. Primary Language of Maine Head Start and Early Head Start-}

Enrolled Families at Home

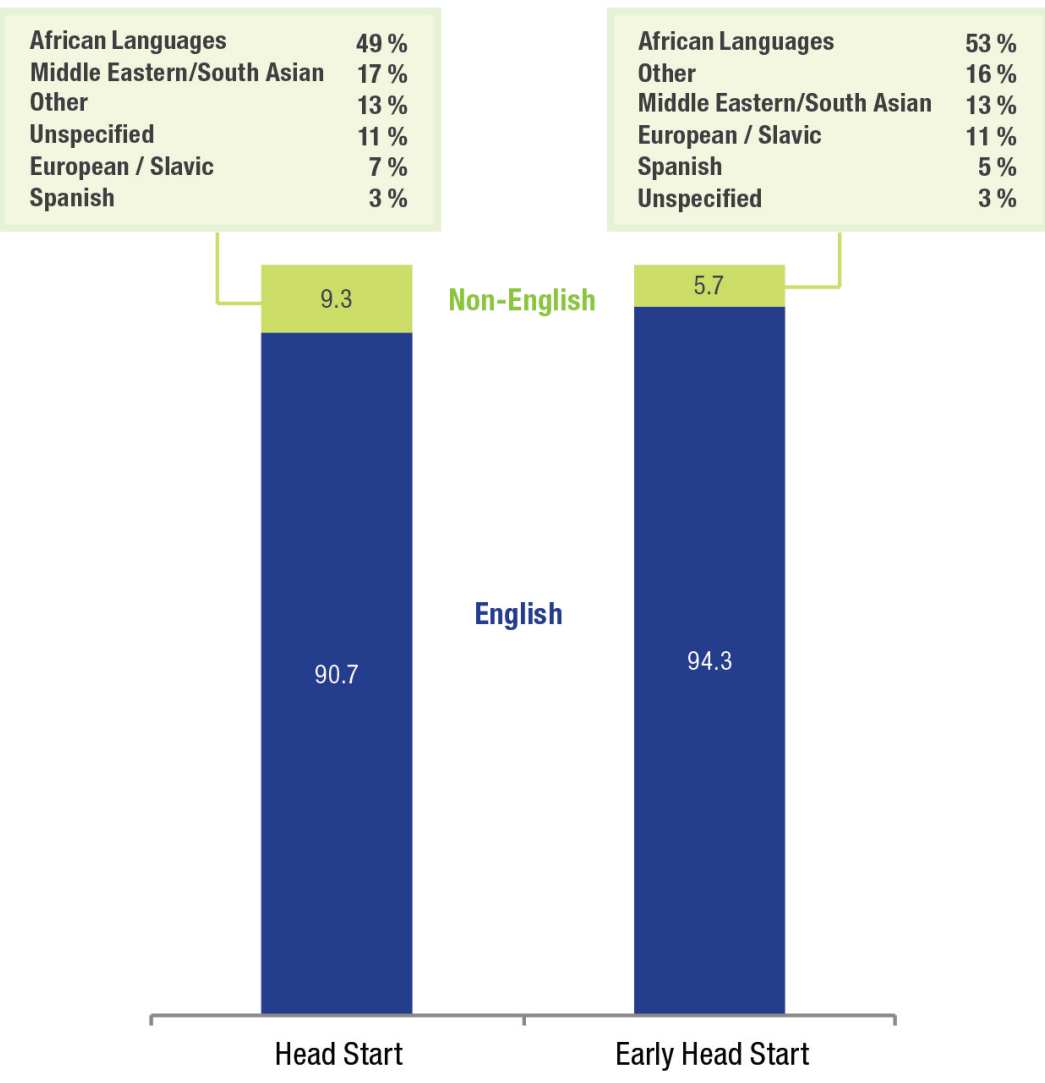


Most Maine children enrolled in Head Start and Early Head Start are nonHispanic white (Figure 9).

\section{Figure 9. Race-Ethnicity of Maine's Head Start and Early Head Start-Enrolled} Children

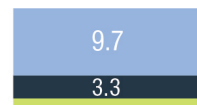

Other/multiracial, non-Hispanic

$$
\text { Hispanic }
$$

8.6

Black, non-Hispanic

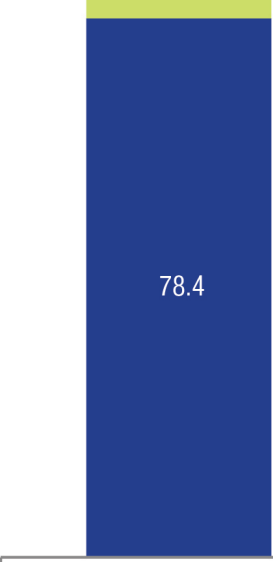

Head Start

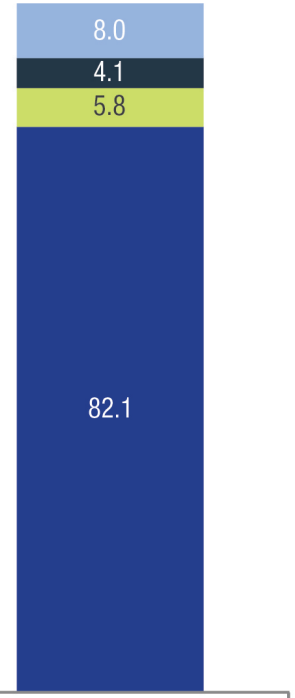

Early Head Start
White, non-Hispanic

Note: Families report their own race/ethnicity for enrolled children.

Maine Head Start and Early Head Start enrollees largely live with one or both parents, in roughly equal proportions (Figure 10). However, a small share of enrollees live with grandparents or in other arrangements, including with other relatives or foster parents.

\section{Figure 10. Family Composition Among Maine's Head Start and Early Head} Start-Enrolled Families

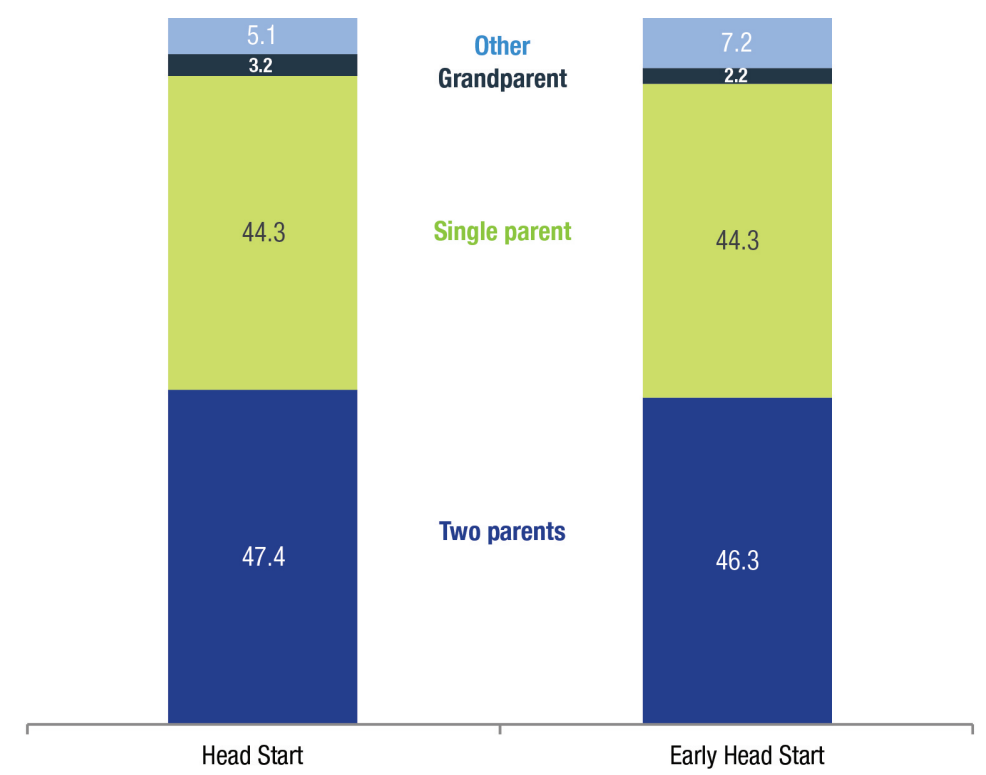


Maine's Head Start and Early Head Start families have diverse educational backgrounds: about four in ten families have a parent with at least some college education (Figure 11).

\section{Figure 11. Educational Attainment Among Maine's Head Start and Early}

Head Start-Enrolled Families

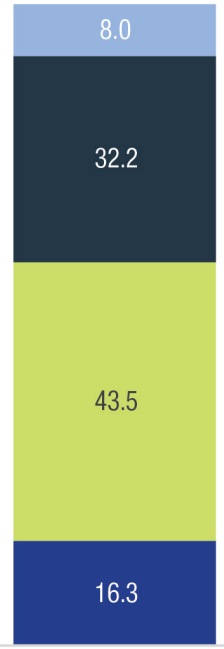

Head Start

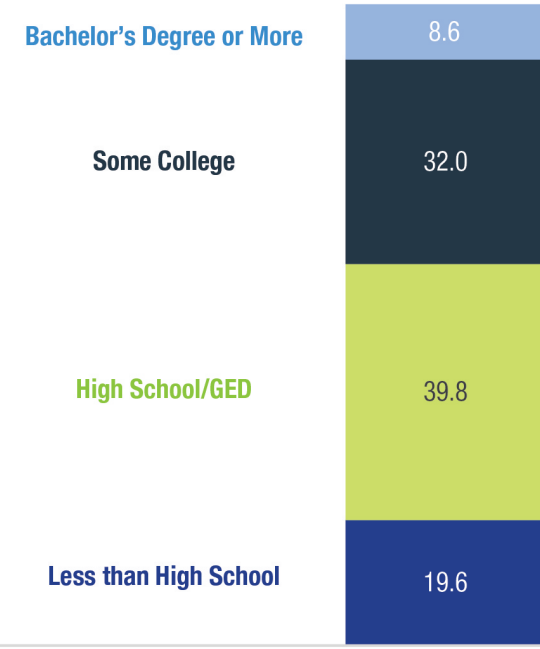

Early Head Start
Note: Families are categorized according to the parent with the highest level of education. "Some college" includes families with an associate degree, vocational school, or some college.
Seventy-one percent of two-parent Head Start families and Early Head Start families have at least one working parent (see Table 3). A smaller share of single-parent families have a working parent-closer to half-although more than one-fifth of single parents of children enrolled in Head Start and Early Head Start are in job training or school.

Table 3. Employment Status and School/Job Training Enrollment for Maine Head Start and Early Head Start-Enrolled Families, by Family Composition

\begin{tabular}{lcc} 
& HEAD START & EARLY HEAD START \\
\hline Of two-parent families: & & \\
Both parents working & 21.3 & 25.7 \\
One parent working & 49.7 & 45.0 \\
Neither parent working & 28.9 & 29.4 \\
Both parents in job training/school & 8.7 & 12.7 \\
One parent in job training/school & 21.5 & 25.5 \\
No parent in job training/school & 69.8 & 61.8 \\
Of single-parent families: & & 47.1 \\
Parent is working & 45.0 & 52.9 \\
Parent is not working & 55.0 & 22.2 \\
Parent is in job training/school & 20.4 & 77.8 \\
\hline
\end{tabular}




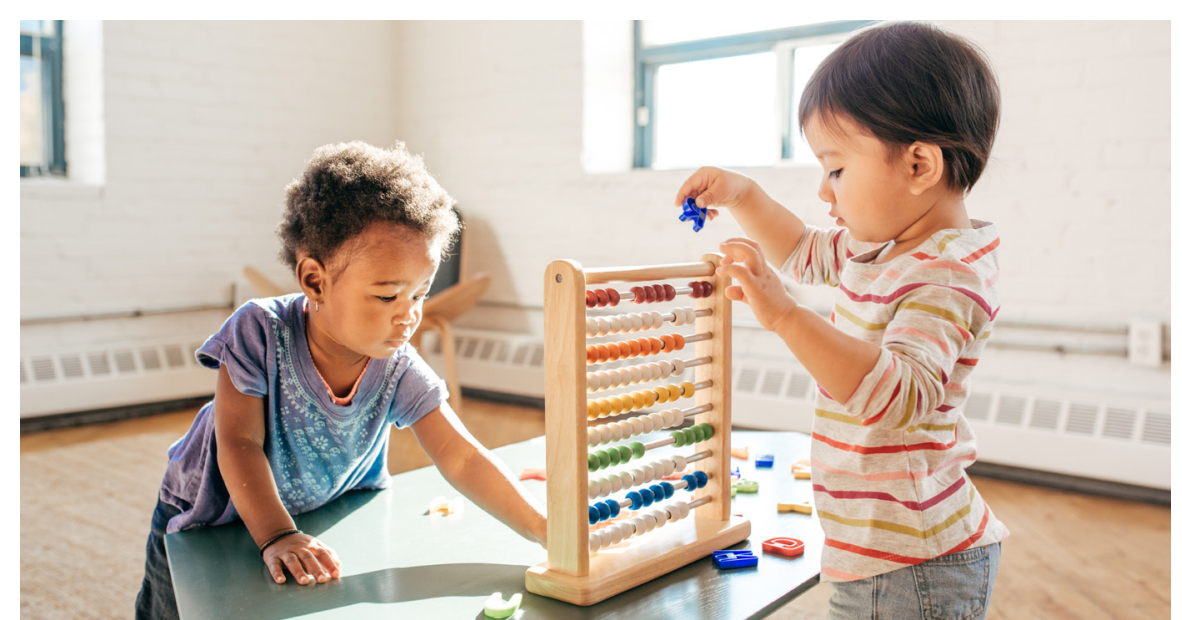

\section{Head Start Staff}

The Office of Head Start requires that at least half of the nation's centerbased Head Start teachers have at least a bachelor's degree in early childhood education or a related field, and that Early Head Start teachers have a minimum of a Child Development Associate (CDA) credential. ${ }^{12}$ Exceeding the national goal, nearly three-quarters of Maine's Head Start teachers have a bachelor's degree, while more than 97 percent of Early Head Start teachers have at least a CDA credential (Figure 12). Education levels are even higher among Maine's Early Head Start home visitors, 65 percent of whom have at least a bachelor's degree.

\section{Box 2: Parents in the Classroom}

One important source of program staff are Head Start parents themselves: several program directors describe substitute teaching as a way to get parents involved and as a way to introduce a potential employment pathway to those parents. Indeed, of the more than 1,300 people employed by Maine Head Start programs, 22 percent are current or former Head Start parents.

Almost 3,000 current and former Head Start parents volunteered in Maine Head Start classrooms in the 2015-2016 program year, making up more than two-thirds of all classroom volunteers.
Figure 12. Education Levels of Maine's Head Start and Early Head Start Teachers

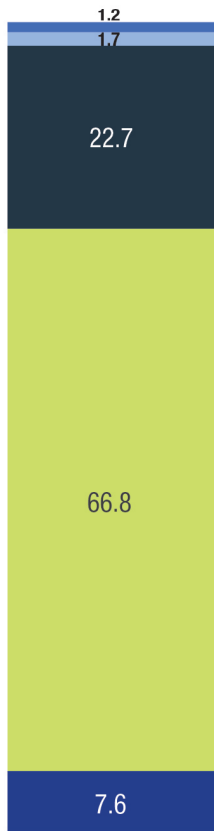

None

CDA Credential

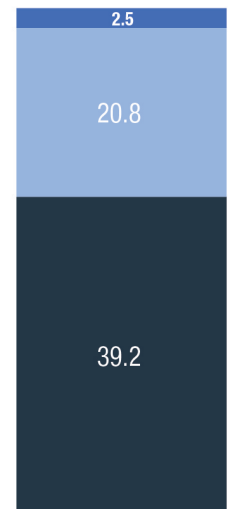

Bachelor's Degree

34.2

Graduate Degree

Head Start

Note: Among center-based teachers only.

\section{Box 3. Staff Turnover}

About 13 percent of Maine Head Start teachers and 10 percent of Early Head Start teachers departed the program during the 2015-2016 program year. Among teachers who left, 28 percent left to seek higher compensation and/or benefits in the same field. 


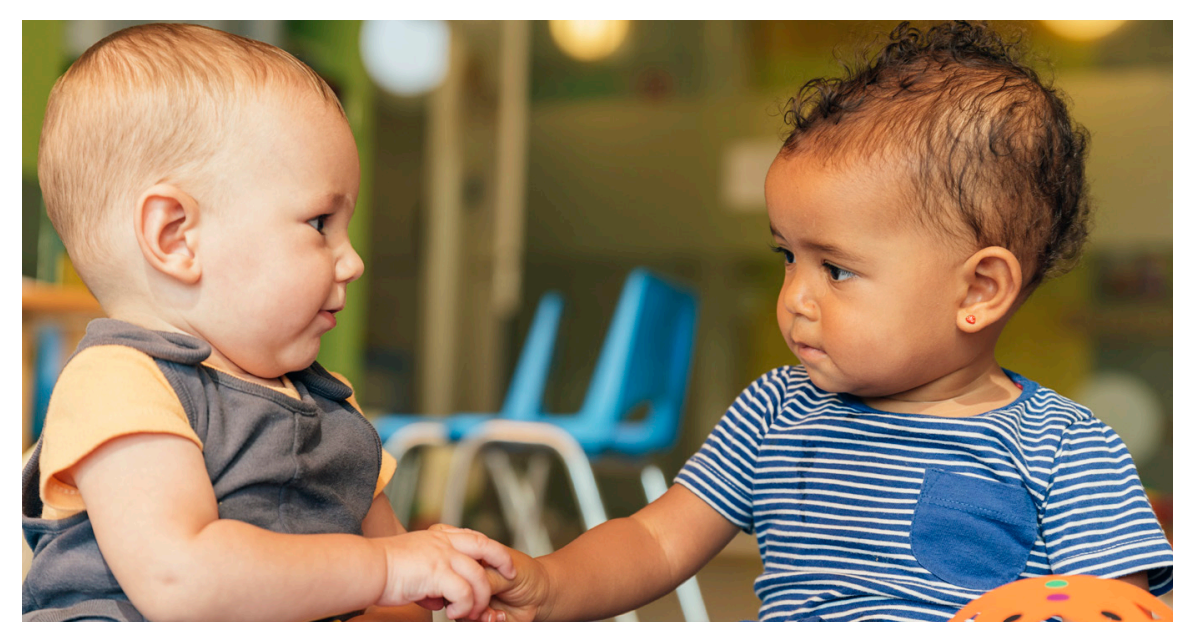

\section{Family Services}

One important component of Head Start is the support that entire families receive from the program staff. Staff refer families who need help to different kinds of emergency and non-emergency services within the community, including assistance with housing, health, substance abuse, or parenting education. More than 3,000 Head Start and Early Head Start families received some kind of service in the 2015-2016 program year.

\section{Box 4. Community Relationships}

One important characteristic of Head Start programming is its embeddedness within the community. Several Head Start directors note the importance of "relationships with community partners" for "connecting [families] with community resources," including those related to education, safe housing, access to food, and mental health services.
Table 4. Service Needs and Receipt Among Maine Head Start and Early Head

Start-Enrolled Families

\begin{tabular}{|c|c|c|c|c|}
\hline & HEAD STAR & & EARLY HEAD S & ART \\
\hline & $\begin{array}{l}\text { Expressed Interest or } \\
\text { Identified Need }\end{array}$ & $\begin{array}{l}\text { Received } \\
\text { Service }\end{array}$ & $\begin{array}{l}\text { Expressed Interest or } \\
\text { Identified Need }\end{array}$ & $\begin{array}{l}\text { Received } \\
\text { Service }\end{array}$ \\
\hline Parenting education & 1,917 & 1,986 & 928 & 1,016 \\
\hline Health education & 1,778 & 1,900 & 891 & 953 \\
\hline Mental health services & 580 & 488 & 215 & 198 \\
\hline $\begin{array}{l}\text { Emergency/crisis } \\
\text { intervention }\end{array}$ & 546 & 527 & 226 & 216 \\
\hline Housing assistance & 454 & 345 & 199 & 188 \\
\hline Adult education & 317 & 261 & 163 & 146 \\
\hline Job training & 198 & 151 & 94 & 95 \\
\hline Asset building services & 170 & 140 & 59 & 66 \\
\hline $\begin{array}{l}\text { Child abuse and neglect } \\
\text { services }\end{array}$ & 142 & 136 & 56 & 60 \\
\hline Child support assistance & 124 & 77 & 51 & 38 \\
\hline $\begin{array}{l}\text { Substance abuse } \\
\text { prevention }\end{array}$ & 70 & 68 & 24 & 40 \\
\hline Substance abuse treatment & 55 & 42 & 20 & 18 \\
\hline $\begin{array}{l}\text { Assistance to families of } \\
\text { incarcerated individuals }\end{array}$ & 54 & 33 & 13 & 15 \\
\hline Domestic violence services & 54 & 30 & 21 & 18 \\
\hline $\begin{array}{l}\text { English as a second } \\
\text { language (ESL) training }\end{array}$ & 49 & 53 & 32 & 29 \\
\hline $\begin{array}{l}\text { Relationship/marriage } \\
\text { education }\end{array}$ & 34 & 20 & 16 & 17 \\
\hline $\begin{array}{c}\text { Number of families } \\
\text { counted } \\
\text { at least once }\end{array}$ & 2,211 & 2,345 & 1,017 & 1,041 \\
\hline
\end{tabular}

Note: Families who "received service" are those who "received services directly through the program or through program referrals." Staff are instructed to "count only those families that actually received the services, not those that were referred and either did not go or were not yet able to receive the services due to denial or postponement." See p. 56 in the 2015-2016 Head Start Program Information Report. 
Perhaps related to the services families receive, data show improved child outcomes throughout the year, including higher rates of health insurance coverage and children being more often up-to-date on preventive health care (Figures 13 and 14). ${ }^{13}$

Figure 13. Percent of Maine Head Start and Early Head Start Enrollees With Health Insurance Coverage Over Enrollment Year

\section{At Enrollment At End of Enrollment Year}
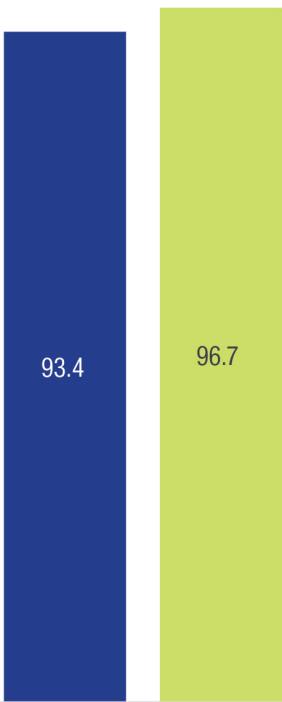

Head Start

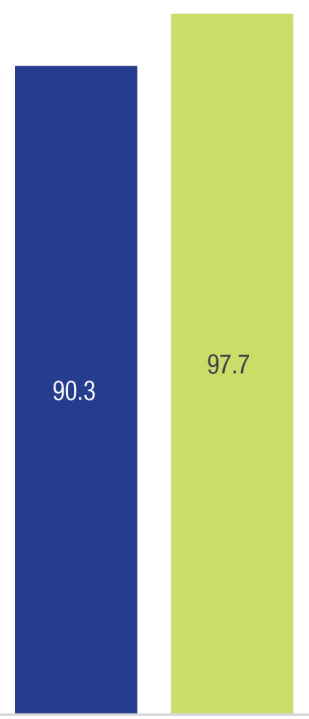

Early Head Start
Figure 14. Percent of Maine Head Start and Early Head Start Enrollees Who Are Up-to-date on Preventive and Primary Health Care

At Enrollment

At End of Enrollment Year

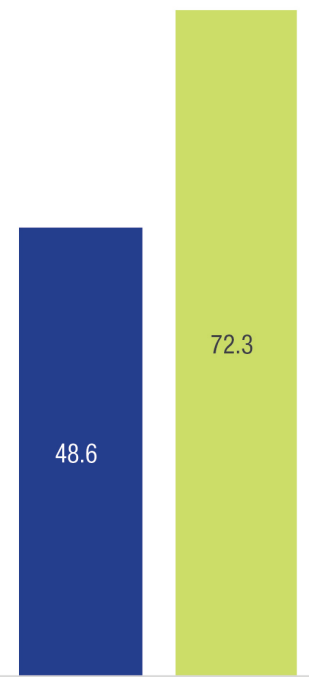

Head Start

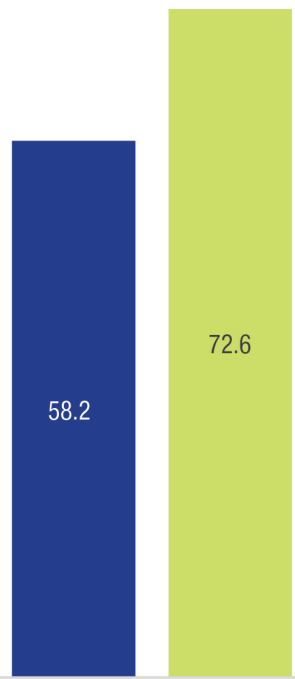

Early Head Start
Note: This item refers to the percent of enrolled children who are "up-to-date on a schedule of age-ap propriate preventive and primary health care, according to the relevant state's EPSDT [Early and Periodic Screening, Diagnostic, and Treatment] schedule for well child care." See the 2015-2016 Head Start Program Information Report. 


\section{Endnotes}

1. Office of Head Start, Administration for Children and Families, U.S. Department of Health and Human Services, https://www.acf.hhs.gov/ohs.

\section{Ibid.}

3. Note that this number indicates cumulative enrollment; that is, all children and women "who have been enrolled in the program and have attended at least one class or, for programs with home-based options, received at least one home visit." Definition from 2015-2016 Program Information Report form; newer forms are available at https:// eclkc.ohs.acf.hhs.gov/data-ongoing-monitoring/article/program-information-report-pir. Unless otherwise noted, data for this report are sourced from the Office of Head Start's Program Information Reports; calculations are the author's own. Access to these data are available upon request through the Office of Head Start, via the Head Start Enterprise System. See https://hses.ohs.acf.hhs.gov/pir/ for contact information.

4. “Head Start Program Facts, Fiscal Year 2015," https://eclkc.ohs.acf.hhs.gov/data-ongoing-monitoring/article/head-start-fact-sheets.

5. For details on the American Recovery and Reinvestment Act expansion, see https:// eclkc.ohs.acf.hhs.gov/about/ohs/history/timeline, 2009. For details on the sequestration-related cuts, see https://eclkc.ohs.acf.hhs.gov/about/ohs/history/timeline, 2013 See also https://www.usatoday.com/story/news/nation/2013/08/19/stateline-headstart/2671309/ and https://www.washingtonpost.com/local/education/head-starteliminated-services-to-57000-children-in-us-as-a-result-of-sequester/2013/08/18/ e1181810-06d9-11e3-9259-e2aafe5a5f84_story.html?utm_term=.60a99abfaa36.

6. Specifically, changes to Head Start staff education requirements at the individual level became effective October 1, 2011, while benchmarks for the nation as a whole became effective September 30, 2013. For more details, see "Statutory Degree and Credentialing Requirements for Head Start Teaching Staff, ACF-IM-HS-08-12,” U.S. Department of Health and Human Services, Administration for Children and Families, https://eclkc. ohs.acf.hhs.gov/archive/policy/im/acf-im-hs-08-12-attachment.

7. "U.S. Federal Poverty Guidelines Used to Determine Financial Eligibility for Certain Federal Programs," U.S. Department of Health and Human Services, Assistant Secretary for Planning and Evaluation, https://aspe.hhs.gov/2015-poverty-guidelines. Note that these poverty guidelines vary from the official poverty thresholds used by the U.S. Census Bureau and others, which vary by age as well as by household size. For more detail on the official poverty thresholds, see https://www.census.gov/data/tables/ time-series/demo/income-poverty/historical-poverty-thresholds.html.
8. The number of poor children is an estimate derived from author's analysis of American Community Survey 2015, 5-year microdata (IPUMS-USA, University of Minnesota, www.ipums.org). Note that this calculation uses 5 years of Census data to accurately estimate the number of poor, young children in Maine, so the time periods for funded enrollment and poor children differ (2015-2016 program year versus 2011-2015 ACS data). Also note that data do not allow for estimation of the number of poor pregnant women, so the target population is actually larger than that listed here. The Census estimation of poor children uses the statistical definition of poverty, rather than the Department of Health and Human Services version, so there is slight variation between those thresholds. Finally, because poverty is not the only indicator of eligibility (others include homelessness and foster child status), the universe of actually eligible potential enrollees in Maine is much higher than the estimated number of poor.

9. Generally, "over income" refers to children with family incomes between 100 and 130 percent of the poverty guidelines. However, a host of statutory exceptions exist; for example, programs in very remote communities can set different eligibility criteria, as can AIAN programs, provided that other guidelines are being met. For more detail on these exceptions, see Head Start Policy \& Regulations, Section 645 Participation in Head Start Programs, https://eclkc.ohs.acf.hhs.gov/policy/headstart-act/sec-645-participation-head-start-programs.

10. Data cited as derived from "Head Start directors" were collected via telephone interview by the author in May and June 2017. More details about this component of the project are available from the author upon request.

11. See, for example, James Cook, "African Immigrants to Maine Are Young, Educated, and Integrating," Central Maine.com, January 7, 2016, http://www.centralmaine. com/2016/01/07/african-immigrants-to-maine-are-young-educated-and-integrating/.

12. Section 1302, Subpart I: “1302.91 Staff Qualifications and Competency Requirements," U.S. Department of Health and Human Services, Administration for Children and Families, Office of Head Start, https://eclkc.ohs.acf.hhs.gov/policy/45-cfr-chap-xii i/1302-91-staff-qualifications-competency-requirements.

13. Note that because the Program Information Report data do not provide a count of children enrolled at the start and end of each program year, percentages in these figures are calculated as a share of cumulative enrollment (that is, as a share of the number of children who attended at any point during the year). As a result, these percentages are underestimates, because not all of the cumulatively enrolled children were necessarily enrolled at the start and end of the program year. 


\section{About the Author}

Jessica A. Carson, $\mathrm{PhD}$, is a research scientist in the Vulnerable Families program at the Carsey School of Public Policy at the University of New Hampshire (jessica.carson@unh.edu).

\section{Acknowledgments}

The author thanks Beth Mattingly, Andrew Schaefer, Amy Sterndale, Jennifer Clayton for feedback on earlier drafts, Laurel Lloyd and Bianca Nicolosi for preparing this report for publication, and Patrick Watson for editorial assistance. The author is especially grateful to Maine's Head Start Directors for their patient and insightful participation in phone interviews for the larger project.

\section{About the John T. Gorman Foundation}

The John T. Gorman Foundation advances ideas and opportunities that can improve the lives of disadvantaged people in Maine. To achieve the greatest impact, the Foundation has a special interest in strengthening families and helping communities provide them with the supports and opportunities they need to thrive.

\section{About the Carsey School of Public Policy}

The Carsey School of Public Policy at the University of New Hampshire is a nationally acclaimed resource for research, leadership development, and engaged scholarship relevant to public policy. We address the most pressing challenges of the twenty-first century, striving for innovative, responsive, and equitable solutions at all levels of government and in the non-profit and for-profit sectors. 



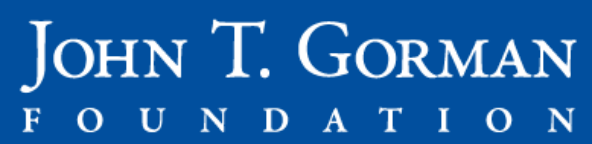

VI University of New Hampshire

Carsey School of Public Policy 